\title{
Summary of an Account of Investigations into the Cause or Causes of the Unusual Mortality among Oysters in English Oyster Beds during 1920 and 1921.
}

Compiled from Chemical Reports By

(1) G. Stubbs, C.B.E., F.I.C.; A. More, A.R.C.Sc., F.I.C., and J. Nicholls, B.Sc., F.I.C., at the Government Laboratory.

(2) O. L. Brady, D.Sc.

Bacteriological Reports by Prof. J. Eyre.

Biological Investigations by J. H. Orton, D.Sc.

By

J. H. Orton, D.Sc.

(Assisted in Laboratory Work by Miss EDITH WORSNOP, M.Sc.)

CONTENTS

\section{Preface}

Summary

Normal mortality and review of literature on oyster mortality, diseases and pests

Abnormal mortality reported among oysters in Europe, 1919-21 . . 3

Abnormal mortality reported among oysters on English oyster beds, 1920-21 5

A. Thames Estuary Area ;-

(1) Physical conditions

(2) Oyster pests .

(3) Investigations for parasites

Investigations regarding possible direct poisoning by dumped munitions :-

(1) T.N.T.

(2) Nitrites

(3) Oil

(4) Copper, zine and some other metals than arsenic

(5) Arsenic in oysters and soils . . . . . . . 17

(6) Sodium picrate . . . . . . . . . . . . 20

B. Isle of Wight and Swansea areas . . . . . . . . . . 20

Experiments on oysters . . . . . . . . . . . 21

Concluston . . . . . . . . 21

NEW SERIES. - VOL. XIII. No. 1. DECEMBER, 1923. 


\section{PREFACE.}

Os October 28th, 1920, a conjoint meeting was held by representatives: of the Development Commission, the Ministry of Agriculture and Fisheries and the Oyster Merchants and Planters Association to institute investigations into the cause of the abnormal mortality which had occurred among oysters in the oyster beds in the Thames Estuary during the summer of 1920. As a result of this meeting investigations were begun under the general direction of the writer. On the completion of the work a full report of the results obtained was forwarded to the Fisheries Department, Ministry of Agriculture and Fisheries. The more important parts of that report will be published as follows: Part I, Main Report, Fishery Investigations, Ministry of Agriculture and Fisheries, London, Series II, Vol. VI, No. 3, 1923 ; Part II. containing the more important Appendices, will appear later.'

\section{SUMMARY.}

Normal Mortality and Review of Literature on Oyster Mortality, Diseases and Pests.

The investigations herein described relate to the European oyster (Ostrea edutis) unless otherwise noted.

The normal mortality of oysters on English oyster-beds is estimated by oyster-planters at 10 per cent in locally grown oysters, and at least 15 per cent in relaid oysters, and is stated to occur chiefly in summer. It has been found that the bulk of the mortality does actually occur in summer, and is correlated with the spawning period.

Heavier mortality than is usual may occur in or follow severe winters.

There is some reason to believe that unusual mortality which has been attributed vaguely to physical causes - apart from the effects of severe frost-may have occurred formerly on English oyster beds.

Dutch oyster planters consider a 20 to 25 per cent mortality normal, and Hoek has shown that on some occasions the summer mortality has reached higher levels, estimated at upwards to 50 per cent. Figures given so far for mortality in the sea are estimations and not accurate determinations.

Holt's experiments on the West of Ireland-carried out admittedly under disadvantageous conditions-resulted in very heavy mortalities in the second year after relaying, and agree in this respect with Hoek's experience.

These findings are important, and show that in relaid oysters an induced physiological weakness, due to unfavourable conflitions during and/or after relaying, may or may not show itself in a high mortality rate during the 
first summer after relaying, while a very high rate of mortality may occur in the second summer after relaying.

It is not inferred that high mortalities follow all relayings.

The cause of the bulk of the the mortality has in no case been assigned definitely, but there is a vague, tacit indication in the writings of workers that fundamental functional disturbances are suspected, while here and there a suspicion of parasites is mentioned without however offering any valid ground for this suspicion. No evidence exists anywhere of any bacterium or Protozoan or allied internal parasite causing the death of oysters in the sea. Many predatory enemies of oysters are known and recognised, but the extent of the depredations is not accurately known and must necessarily vary. Great variations in saltness of water over oyster-beds are known to induce weakness or cause death of oysters, and great variations in salinity and temperature at about the spawning period are believed to be dangerous to the health of oysters. Ice-cold water if of low salinity is also known to be specially harmful to oysters.

There can be no doubt therefore that different oyster beds will have different mortality rates, and that the rates will vary with the local physical conditions, the presence or absence of pests, and finally the method of cultivation.

\section{Abnormal Mortality Reported Among Oysters in Europe,}

$$
\text { 1919-21. }
$$

A great mortality of oysters was reported from the region of Taranto South Italy, during the winter of 1919-20. No report of investigations in that area has been published at the moment of writing, but reports have been received by letter that a filiform bacterium, obtained in1919-20 from dying oysters, causes death of oysters when added in cultures to oysters in small vessels. Further evidence is required to substantiate this statement, and no evidence has been adduced to show that the particular bacterium would be harmful to oysters in the sea. No other cause of the mortality has been detected, but bad condition of the water, due to shipping, to adjacent military camps, and to removal of the hull of the sunken Dreadnought, Leonardo da Vinci, is believed to have occurred.

An unusual mortality of oysters was also reported from the beds on the west coast of France, from Morbihan to Cape Finisterre, in 1920, and at these places and others in the English Channel in 1921. No dangerous bacterial or other parasite has been discovered in hockley oysters from these regions, and no explanation of the mortality is put forward, other than the rapid fall in temperature in June, 1920, after previous unusually warm weather. It is reported, however, that oysters wholly grown in 
claires did not show unusual mortality, whilst oysters in the sea-and apparently on beds adjacent-did show unusual mortality. It would, therefore, seem clear that temperature variations will not explain the absence of mortality in claires, since the practically stagnant water of the claires would follow atmospheric changes much more closely and quickly than the water in even shallow estuaries.

A mortality of upwards to 70 per cent is reported from oysters dredged at Brest, and 30 per cent at Quiberon, but as in the case of English beds these are estimations, and the normal mortality is not stated. At Arcachon, on January $15 / 21$, it is stated that the mortality fell to 4 per cent, a figure regarded as below the normal, but as this figure is far higher than that estimated for any English oyster bed at any time it would appear that the normal mortality on French beds is much higher than on English beds. No unusual mortality of Portuguese oysters (O. angulata) occurred on French oyster beds in 1920 .

The mortality reported from Dutch oyster beds in 1920 was also high, but high summer mortalities on these beds are known from previous observations. On the Dutch oyster beds far more attention is paid to salinity and temperature variations than anywhere else. It is known * that in January, 1920, the water was of very low salinity during the greater part of the month, and at times at low water almost drinkable, and there can be no doubt that Dr. Folpmers is right in attributing the mortality observed on these beds to the conditions observed, for the oysters were in very poor condition, as is shown by weight determinations in May and November, 1920. No unusual bacteria were observed in 1920, nor in 1921, on these beds, nor on the Yersche and Bergsche beds, where high mortality also occurred. On the latter beds general neglect and a heavy fall of Ascidian spat, which tended to smother the oysters, are offered with the low temperature $\left(13^{\circ} \mathrm{C}\right.$. as against a normal of $21^{\circ} \mathrm{C}$.) in August, 1920 , as an explanation of the high mortality.

In 1921 there was also an undefined high death rate on the Grevilingen beds which could not be attributed to any of the above causes, but it seems probable that the weakness carried over from the previous year, along with the extended spawning season, is sufficient explanation. The oysters on the Zeeland beds in 1921 are shown by Dr. Folpmers to have been in good condition in June, and to have fattened up well by December.

Reports of unusual mortality in Ireland in 1920 have not been substantiated, but it would appear that there was a slightly higher mortality than usual in many places in 1921, as indeed might be expected. No reports of unusual mortality were received from any other European countries nor from Scotland nor from America in 1920. In England, in

* The following information was kindly given by Dr. Folpmers, Bacteriologist to the Zeeland Fishery Board. 
1920, heavy mortality was reported among oysters in the Thames Estuary, the Isle of Wight region, and off Swansea. In 1921 unusual mortality was again reported from beds in the Thames Estuary and from some beds in the neighbourhood of Falmouth, but the conditions on all beds were not reported upon.

Thus unusual mortality of oysters was reported to have occurred in Italy late in 1919, on the west coast of France, the Thames Estuary, and probably also the Isle of Wight and Bristol Channel in the summer of 1920 , and after a cessation in all parts in the winter of 1920-21, reports were again received from the Thames Estuary, English Channel and north and west coasts of France of unusual mortality in the summer of 1921. The mortality in Italy was apparently mainly a winter outbreak, that in France apparently mainly summer, that on English beds distinctly a summer phenomenon wherever it has been closely observed. The mortality at Taranto, Brest, in the Thames Estuary and Isle of Wight reaches is in the region of considerable shipping traffic, that at Quiberon Bay and on beds in the English Channel is not.

Mortalities rather greater than usual may be expected to have occurred. in 1921 owing to the lengthy hot summer, but those for 1920, although accounted for by some workers and oyster planters as due to the peculiar weather of that year, cannot be regarded definitely as due to weather conditions in the present state of knowledge, and have to be considered in relation to the dumping of munitions in the sea during the immediate post-war period, and in relation to any other factors.

\section{ABNORMAL MORTALITY REPORTED AMONG OYSTERS ON ENGLISH OYSTER BEDS, 1920-21.}

\section{A. THAMES ESTUARY AREA.}

Investigations on English beds have been conducted largely in the Thames Estuary and are considered under the following sub-divisions :-

\section{(1) Physical Conditions.}

The abnormal weather of 1920 was believed by many oyster cultivators to be a likely cause of increased mortality of oysters. A study was made of air temperatures and sea temperatures in the environs of the Thames Estuary ; it was found that the mean surface sea temperature at the Shipwash Light-vessel followed the mean air temperature over the Estuary, almost exactly with a lag-period of about fourteen days when reckoned over a period of thirty-eight years. It is shown that temperatures higher up the Estuary would be higher and would follow the mean air temperature much more closely and quickly than in the lower parts of the Estuary. 
Thus mean air temperatures will give a good indication of temperature variations in the sea over oyster beds. Similar temperature variations occurred in the two years 1912 and 1920, except that the mean was higher in July, 1912, and lower in August, 1912, than in the corresponding months in 1920. In a similar manner a study of rainfall indicates that the salinity variations from the average were probably greater in 1912 than in 1920. Thus unusual oyster mortality should have occurred in 1912 if physical conditions were the sole cause. Most oyster planters report normal mortality or no record for 1912, but one or two report much death. It is certain that wherever spawning oysters are subjected to relatively cold water of low salinity for any appreciable length of time increased weakness and mortality would follow. Thus an undeterminable increase in mortality may be expected to have occurred in river beds and beds in shallow and narrow estuaries in 1920, but it is considered that the actual amount of increase in mortality would be only a small portion of the excess of mortality estimated on oyster beds for 1920: off-shore oyster beds, as at Whitstable, would be affected to a much less extent by weather conditions, and only slight mortality due to those conditions may be expected to have occurred there in 1920 .

In 1921 the prolonged hot summer can certainly be connected with increased mortality (1) by the exposure of oysters on beds between tide marks to prolonged heating by the sun, and (2) by an extension of the spawning period of the oyster, and thereby increasing mortality associated with spawning. It is considered that many reports of unusual mortality in 1921 are accounted for satisfactorily in this way, and are generally of less importance than those issued in 1920 .

\section{(2) Oyster Pests.}

No unusual pest was reported or found on oyster beds in the Thames Estuary in 1920 or 1921. The Blackwater beds had few burrs (Echinus miliaris) and starfishes (Asterias rubens) in 1920, and whelk-tingle (Murex erinacea) was stated to be not unusually abundant. No other pests were noted at the end of October, 1920. The beds off Whitstable showed large numbers of burrs and starfishes in November, 1920, and afterwards, but were apparently not more abundant than usual. On these beds it was found that in five months in 1921 in an experimental cage the mortality due to burrs was $3 \cdot 2$ per cent, or at the rate of 8 per cent per year, and that possibly - but not certainly - due to star-fishes 11.4 per cent in five months. It is pointed out that mortality due to these pests is certainly higher than has been realised, and further experiments are called for to determine it more accurately.

The mortality on the above-mentioned beds was, however, certainly due largely to other causes than the pests noted. 
(3) Investigations for Parasites.

In the early period of the investigations sound and weak oysters and samples of sea water were examined in various ways for bacteria by Professor Eyre, but apart from the discovery of two undescribed organisms which were found by experiment to be harmless to oysters, little difference was found qualitatively between sound and weak or dying oysters, and no evidence could be obtained of any dangerous bacterial parasite. Professor Eyre's examinations were carried out mainly at relatively high temperatures, but fortunately a general infection experiment was carried out concurrently with the above examinations in the tanks at Plymouth at sea temperatures. In this experiment batches of so-called diseased oysters were kept in tanks in contact with sound oysters without causing any significant mortality over a period of more than a year. Cultures of oyster tissues in oyster broth was found to yield various organisms and fed to oysters at Plymouth with impunity: it is therefore regarded as highly improbable that any lethal infectious parasite was present in oysters after October, 1920. Careful examination of numerous freshly dead, weak and sound oysters, has led to no discovery of parasites which can be considered dangerous, nor has any dangerous parasite been found in the examination of microscopic sections of portions of fifty oysters. It is, nevertheless, impossible to state definitely that parasitism is not the cause of the unusual mortality observed, but it can be said that it is at least very doubtful that the mortality of oysters after October, 1920, has been due to parasites.

\section{(4) Observations on "Hockley" and Sound Oysters.}

A "hockley" oyster is one which sounds hollow when struck with a hard object, or is gaping slightly. The occurrence of hocklers is well known and slightly different terms are used to describe them in different parts of this country and elsewhere.

Oysters may become hockley from a variety of causes, temporary or permanent, and there is every reason to believe that all individuals which may be moribund from most or all the ills to which oysters are liable become hocklers eventually. Other bivalves may become hockley in the same way as oysters; thus one may speak of hockley clams.

The supposed diseased oysters of the Thames Estuary of the summer of 1920 and 1921 were hocklers which, however, were frequently wellfished individuals in good condition, and in other respects sound. Of 700 bona-fide hocklers - i.e. gaping for no obvious reason-transported from Whitstable to Plymouth tanks late in 1920, 10 per cent recovered even after making the railway journey in a more or less gaping condition. 
From records kept for the writer by the Seasalten and Ham Oyster Co.,. Whitstable, it is clear that the occurrence of hocklers is seasonal, varying from a minimum of about 1 in 1000 or even 1 in 3000 in winter to about 1 in 100 at about July, as estimated from freshly dredged. oysters examined within about twenty-four hours. At the end of: October, 1920, the proportion was given as 1 in 400 , and at once showed diminution.

Little is known of the pathology, physiology and even histology of: the oyster. The parasites found in weak oysters were all regarded as. secondary and attracted by the poor or dying condition of the oyster.

Various hitherto undescribed symptoms observed in weak or dying. oysters, and at first thought to be abnormal, were afterwards found to be probably normal; such as degeneration of ova in the gonad; curious, highly vacuolated cells present only in the gonad of recently spawned oysters; protoplasmic processes on the sperm morulæ probably serving as channels of nourishment in development; and possibly also the phenomenon of diapedesis or bleeding; heavy concentrations of blood cells around the gut; the occurrence of cysts and excretory deposits on. the shell and the occurrence of numerous gland-cells in the stomach and. other parts.

In a few oysters were found large suppurations involving relatively large portions of the body - in two cases involving the whole of the stomach. Large suppurations have been recorded previously by Ryder and Giard. In 824 hockley oysters 3 per cent were found to have cysts or suppurations, but a similar percentage was found in 230 . sound oysters examined. Excretory deposits on the shell were found in 14.9 per cent of hockley oysters of which 1272 were examined between February 9th and May 10th, 1921.

Some hocklers and some sound oysters also were found to show fatty degeneration of patches of the epithelium in the stomach and other parts of the gut.

The most constant symptom observed in hockley oysters is the occurrence of microscopic muscle spindles throughout the tissues of such oysters. These muscle spindles have so far as is known not been observed beforein oysters; they vary in size from about $8 \times 2 \mu$ to $90 \times 20 \mu$, but were commonly from $20 \times 6 \mu$ to $40 \times 10 \mu$, while there is also much variation in width of spindles of the same length. They were observed first in an oyster on October 30th, 1920, but a considerable time elapsed beforethey were finally recognised as muscular in origin.

Spindles were frequently observed late in 1920, but their frequency was not determined. A sample of 53 fresh hocklers examined June 8th to July $20 / 21$ for these muscle spindles, showed 60 per cent with few orabundant spindles, while samples amounting to 217 sound oysters, 
examined June/August, 1921, showed $9 \cdot 6$ per cent with few or abundant spindles.

There is no doubt that the spindles are the product of muscular degeneration or myolysis, a phenomenon unknown elsewhere in Invertebrates until 1922 when De Horne described similar myolytic spindles in metamorphosing Polychætes. The source and cause of the formation of myolytic spindles in oysters has not been determined, but the adductor muscle is now strongly suspected as one source, but there may be other sources.

Spindles can be produced in oysters as artifacts, by bruising the tissues, while starvation also appears to tend to their formation, but poisons haveso far failed to produce them in significant quantity; they have been met with sporadically in sound young oysters from the Plymouth as well as Mersea districts ; in a hockler at Falmouth ; in a culture experiment; in oysters starved in tanks at Plymouth; and in a few oysters from arsenic, T.N.T., and mercuric chloride experiments. In some of these oysters a few spindles only were found in the pericardium, but in others abundance occurred in the tissues. It is possible that myolytic spindles may occur normally in oysters, and Miss Worsnop has made the feasible suggestion that the spindles may be derived from the adductor and other muscles as migration occurs with growth of the shell by the assumption that one side of the muscle degenerates whilst the other is growing. It is pointed out that if this is the case then myolysis should occur generally in Lamellibranchs, and indications have already been obtained that this is probably true. Further research in this direction is required. It is insisted, however, that abundance of myolytic spindles in the tissues must be regarded for the present as pathological and requiring further research for an explanation.

Experiments on the period required for the liquifaction of the crystalline style when oysters are taken out of water are given, as also for the reformation of the style on replacing oysters in water. Slow liquefaction and quick reformation of the style occurs in oysters in good condition, while the reverse occurs on the whole in weaker oysters. In very weak oysters the style is absent. Absence of style or slow reformation of the style is correlated with a pale-coloured liver. A good oyster may not liquefy its style for from two to over ten hours after being taken out of water, and may reform it in three-quarters of an hour to two hours. when replaced in water. A weak oyster may lose its style in three-quarters of an hour after being taken out of water, and take several hours to reform it when put back in water. The problem is, however, complicated by the previous treatment of the oysters. Much more work remains to. be done on this subject, but useful results may be expected to follow.

Analyses of hocklers in late 1920 show a majority of them to have been: 
light-livered, but also a fair proportion with dark, healthy-looking livers. Other criteria of health are, therefore, required than good condition, dark liver and presence of style in oysters in water.

Bleeding or diapedesis has been observed in hocklers, but it was found that sound oysters after transportation or exposure to warm air in summer weather frequently bled copiously, and afterwards recovered. Large quantities of blood-cells leave the body, but it is not possible to see whether blood-fluid is always lost at the same time; apparently bloodfluid is only rarely lost, and no evidence has been obtained of rupture of the body wall: thus a true diapedesis is suspected. It is surmised, therefore, that the phenomenon may be purely a physical effect, namely, that certain conditions in the mantle cavity of the oyster induce the blood-cells to migrate from the body in few or even vast numbers. Diapedesis may, therefore, be a secondary symptom of hockley oysters.

The occurrence of myolysis, cyst-formation, and excretory deposits on the shells in hocklers, all suggest that there is a suspicion of a small proportion of oysters suffering from inflammatory causes of a nature so far undetected, but the readiness with which the tissues of the allies of the oyster are known to react to foreign bodies of no specially harmful nature render it doubtful that cyst-formation - for instance - is necessarily caused by poisonous substances. It is well known that non-toxic foreign bodies and parasites give rise to the formation of pearls in various bivalves.

Myolysis is probably the most serious symptom observed in hocklers, but further researches may be expected to explain the cause or causes.

The blood-cells of the oyster and also of some of its allies have been found to be able to live in ordinary sea water for three to four days outside the body of the oyster. This fact gave rise to suspicion at first of the presence of amœba-like parasites in the blood, but no such parasites have been found.

Oysters taken from the beds in October, 1921, and analysed for foodstuffs for comparison with unpublished analyses made by the Government chemist in conjunction with Dr. Wallace (Ministry of Agriculture and Fisheries) during the war showed that the October, 1921, oysters resembled the close season oysters of 1919, thus indicating that at the end of the extended summer of 1921 oysters resembled in condition spawning oysters of a normal summer. Researches carried out by the Public Health Department of the London County Council on the sea water of the Thames Estuary in connection with the disposal of rubbish, etc., indicate that the oxygen content, the salinity and temperature of the water on the line. Nore-Oaze-Black Deeps near the Edinburgh Light-vessel, on the site of the dumping ground were normal, or subnormal, in the year 1920. The salinity of the Thames Estuary water was high in the latter half of 1921, 
but not higher than has previously been recorded by Dickson (1894). The oxygen requirements of the oyster and its allies are discussed, and it is shown that oysters can live for at least several days without an external supply of oxygen and recover, but further research is required to establish the minimum amount of oxygen which oysters can live in for extended periods, and the effects on oysters of water super-saturated with oxygen.

Oysters in various conditions - and other material - have been preserved at all stages of the investigations for the purpose of comparison in the eventuality of some malignant symptom being found in oysters in the future; a list of the preserved material is given.

\section{INVESTIGATIONS REGARDING POSSIBLE DIRECT POISONING BY DUMPED MUNITIONS.}

Complete lists of munitions dumped by the Ministry of Munitions in the Thames Estuary and in other localities, down to the end of 1920, and extensive lists of cargoes lost at sea in vessels carrying munitions and other dangerous materials are given and discussed. Many cargoes still remain to be traced and their dangerous nature to oysters investigated. No cargo has been found, however, which can be definitely connected with oyster mortality in the Thames Estuary.

\section{(1) T.N.T.}

It is known that 1250 tons of T.N.T. were dumped in the Thames Estuary during the period 1919-20, and, therefore, special attention has been given to estimating the effect of the T.N.T. dumpings on oysters on the oyster beds in that locality, and a variety of experiments have been carried out to determine the effect of definite concentrations of T.N.T. on oysters and other marine animals and the rate of destruction of T.N.T. in sea water; while in November, 1920, samples of water were collected from all parts of the Estuary and tested for the presence of T.N.T. and allied substances. Although much work has been done on the reactions of T.N.T. much more could have been done with profit but for the limitations of the money available.

Fourteen samples of water from the environs of the Thames Estuary (21 Oct.-29 Nov., 1920) were found to contain no T.N.T. with Brady's test which will detect one part of T.N.T. in fifty millions of water.

Control tests with T.N.T. in seawater, made in 1922, show that T.N.T. in solution at the time of sampling would not alter appreciably-if at allin the time which elapsed between the taking of the samples and the time of examination.

Thirty-eight separate samples of particles caught in fine silk nets floating near the bottom in representative situations in the Thames 
Estuary showed no T.N.T. present except possible traces in two cases. (9th and 15th Nov.). Only three of these samples were treated to ensure preservation of any T.N.T. that might be present, but tests carried out later showed that grains of T.N.T. one-fiftieth of an inch in diameter remain practically unaltered in a week in samples of floating particles captured in a similar way and with similar organisms present, as in the case of the 1920 samples.

Thus it can be stated that no appreciable nor significant amount of T.N.T. was present in solution or as floating particles in representative situations in the Thames Estuary after November, 1920

The rate of solution and saturation of T.N.T. in sea water varies very slightly at temperatures almost within the limits of the variation in temperature of sea water in the Thames Estuary, namely, at $37^{\circ}$ and $63^{\circ} \mathrm{F}$.

T.N.T. dissolves very rapidly to saturation point in a small constant volume of seawater kept constantly agitated, attaining a saturation-point of 110 parts in a million in twenty-four hours at about $62 \cdot 6$ to $64 \cdot 4^{\circ} \mathrm{F}$., and 105 parts in a million at about $37^{\circ} \mathrm{F}$., but it dissolves very slowly in the sea and in tanks; a lump of T.N.T. lost less than 3 per cent by weight after being in a tank with frequent stirring of water for seven months, while a piece of T.N.T., weighing about 3 to $3 \frac{1}{2} \mathrm{lb}$., kept in a cage in the sea, lost by solution probably less than 20 per cent in eight months, but certainly less than 30 per cent by solution and abrasion. A greyish deposit acquired by the T.N.T. in the tank certainly interfered with the solution, but the T.N.T. in the sea had the appearance of a clean fresh surface when hauled.

Samples of Berkefeldt-filtered sea water, made up to one part T.N.T. in four millions and one part in thirty-three millions, remained unaltered in this sterile water after twenty-six hours. Many samples of ordinary sea water, made up to the order of one part T.N.T. in five to thirty millions. of water, were found to have lost approximately one half of the T.N.T. within about eighteen hours or less. Samples of ordinary sea water containing living larvæ of the rock-barnacle made up to one part T.N.T. in eight millions was found to have been reduced to one part T.N.T. in twenty millions on examination eighteen hours later; the larvæ were living: one part T.N.T. in five million did not affect the larvæ until after four days, while one part T.N.T. in ten million had no effect on the larvæ, so long as the larvæ could be kept alive (about six days).

Solutions of T.N.T. made up to estimated known strengths of the order of one part T.N.T. in thirty to seventy thousand of sea water are found to. lose from 30 to 76 per cent of the T.N.T. in solution in periods of from eight to four months when kept in diffuse light or diffuse sunlight. In sunlight the loss of T.N.T. is just perceptible in nine days; the destruction of: 
T.N.T. in this case appears to depend largely, if not entirely, on the intensity of the light. Powdered T.N.T. is decomposed very rapidly in direct sunlight.

Thus T.N.T. in a made-up solution remains constant for a period of about nine days even in diffuse sunlight but is afterwards gradually decomposed. Solutions of T.N.T. added to sterile water give a dilute solution which remains unaltered for a period, but solutions of T.N.T. added to water containing organisms quickly lose a portion of the T.N.T. by inter-action with the organisms. The organisms present in an ordinary sea water sample are sufficient to reduce the strength of dilute solutions of T.N.T. by half in eighteen hours, but by more than half if small living organisms be added. T.N.T. in solution, therefore, reacts with organisms in sea water and afterwards reacts with the chemical constituents of sea water when exposed to light. The products of decomposition of T.N.T. in contact with sea water in the presence of light are either not at all toxic or only slightly toxic, but further research is required to obtain more information.

The products of the decomposition of T.N.T. in solutions of the order of one part in 130,000 had no effect on oysters in Tank 4 in the Millport Experiment during a period of three and a half months.

The readiness with which oysters succumb in solutions of T.N.T. depends upon the strength of the solution of T.N.T. and the time oysters are subjected to solutions. A saturated solution of T.N.T. (ca, $1: 10,000$ ) will kill oysters in two or three days.

Oysters in water in bell-jars to which lumps of T.N.T. are added succumb in from four to seven days.

In a tank containing about 600 litres of water and excess of powdered T.N.T. for saturation it took three weeks to kill thirty nine oysters.

In a similar tank containing a lump of T.N.T. about $\frac{1}{2}$ lb. in weight it took five months to kill forty two oysters.

In four tanks placed in series each containing about forty oysters and fed by freshly pumped water for sixteen weeks from a tank containing $10 \mathrm{lb}$. of crushed fresh T.N.T. no significant amount of death occurred in the last tank in the series, which is estimated to have contained T.N.T. in solution of the order of one part in five million.

In an experiment carried out in the sea less death of oysters was experienced in eight months in a cage containing 3 to $3 \frac{1}{2} \mathrm{lb}$. of T.N.T. than in a similar cage in an adjacent situation without T.N.T.

On the wooden container of the T.N.T. in the sea a variety of different animals settled as larvæ and grew both on the inside and practically touching the T.N.T., and on the outside.

The loss of weight of the lump of T.N.T. in the sea experiment shows that only excessively dilute solutions of T.N.T. could have occurred even in the immediate vicinity of the T.N.T. Calculations of the possible 
extent of solutions of T.N.T. in the sea can only be made on hypothetical conditions; on the most favourable hypothetical conditions for solution of T.N.T. in the Thames Estuary it would appear that this substance could never have attained a concentration likely to affect oysters on oyster beds in any way.

Oysters reject grains of T.N.T. forcibly injected into the mantle cavity and are known to reject noxious foreign particles. It is considered unreasonable in relation to the dumping of T.N.T. that any considerable quantity of grains of T.N.T. can have been present on oyster beds in 1920 and caused unusual mortality.

The conclusion is arrived at that unusual mortality of oysters was not due to T.N.T. in solution, nor to the ingestion by oysters of grains of T.N.T., but that it is possible that a small and negligible amount of death may have occurred by the latter means.

(2) Nitrites.

In January and May, 1921, the amount of nitrite, estimated as nitrogen, present in the water of the Thames Estuary in representative situations was found to be from 0.00020 to 0.00057 parts in 100,000 parts of water. These figures are normal for estuarine situations as is shown by results previously obtained by other workers and analyses of other samples from Plymouth Sound and Helford River, An experiment carried out in a tank at Plymout, in stagnant aerated water, containing at the beginning of the experiment 450 (four hundred and fifty) times the normal amount of nitrite, showed that even this high concentration of nitrites had no appreciable effect on oysters and many other marine animals during a period of eleven weeks. A sample of the experimental oysters kept in tanks for nine months after the experiment showed that no ill effects had resulted. The excess of nitrites in the experimental tank was gradually destroyed presumably by bacteria.

Nitrites are regarded, therefore, as not even a probable cause of mortality among oysters in the Thames Estuary in the summer of 1920.

Large variations of nitrites were found in Plymouth tanks confirming earlier unpublished researches by Matthews.

In the sea there is evidence that nitrite formation occurs largely in winter, but it is known also that nitrite formation from sewage takes place rapidly at relatively high temperatures in water poor in oxygen.

(3) OIL.

An experiment with oil taken from the sea at Whitstable and identified at the Government laboratory as petroleum residue - carried out in a small bell-jar showed that this substance has little effect on oysters; one oyster lived four months with repeated additions of the oily substance, and some 
sea worms (Ophryotrocha) multiplied abundantly on the tarry scum and were eating it-possibly for the associated organisms. Analyses of the water made at the Government Laboratory at various stages of the experiment are given, and show that traces of oil and acidic bodies in solution derived from the oil were present in the water in solution, but in minute quantities which would be negligible in the sea from even a large quantity of oil.

Mitchell's work showing the relative harmlessness of water-gas tar on oysters is discussed, as is also Shelford's work on the toxicity of the constituents of fuel oils and coal tars and other work on the constituents of oils. Further work on marine animals on similar lines is recommended, especially with regard to acridine found by English workers - in connection with unpublished investigations on the effect of tarred road washings on fresh-water life - to be toxic in the proportion of one part in five million on fresh-water organisms. The eonclusion is arrived at, however, that apart from actual contact of oil with oysters, oil in sea waters subjected to tidal movement may be expected to be harmless to oysters and the oyster planter.

(4) Copper, Zinc, and some other Metals than Arsenic.

It has long been known that copper is present in fair quantity in oysters from certain localities in the neighbourhood of copper deposits and pollutions, as at Mylor Bank, Falmouth, and various places in America, and gives rise to a condition which has been described as green leucocytosis (Herdman and Boyce). Zinc has also been found in large quantities in oysters from all parts of America (Hiltner and Wichman) and from some parts of England (Fishmonger's Co.). Moreover, traces of copper are known to be present in the blood of most Molluscs. The large amounts of various munitions and metals thrown into and lost at sea rendered it desirable to test oysters for as many metals as possible. Mylor Bank oysters, which are known to fatten and breed and to be otherwise apparently healthy, were analysed for metals to obtain a criterion of what oysters could withstand; they were found to contain Copper in the proportion of 290 to 3300 parts per million of oyster meat

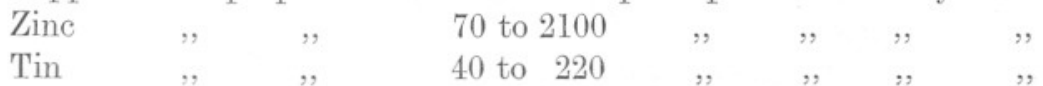
but the latter metal may be absent.

Apparently healthy Pecten from the Mylor Bank and the neighbouring locality were found to have

Copper in proportion of 10 to 690 parts per million of oyster meat

Zine " " $\quad 210$ to $300 \quad$ " $\quad$ ", ",

Tin " " $\quad 0$ to $20 \quad, \quad, \quad$,


Oysters from the Thames Estuary and other beds contain nothing like this proportion of metals, and since no large quantity of them has been known to have been lost at sea near oyster beds it is concluded that copper and zinc have played no part in the reported mortality of oysters.

The normal amount of metals present in sound, edible, English oysters is from 30 to 90 parts of copper and 280 to 480 parts of zinc with upwards to 40 parts of tin and upwards to 90 parts of iron per million parts of oyster meat: in good eating oysters of an average weight of $10 \mathrm{grams}$ there would be respectively approximately $\frac{1}{200}$ th to $\frac{1}{\tau 0}$ th grain of copper, approximately $\frac{1}{25}$ th to ${ }_{15}^{1}$ th grain of zinc, upwards to $\frac{1}{70}$ th grain of iron and in some cases upwards to $\frac{1}{180}$ th grain of tin, and as has been shown, probably also traces of arsenic.

It seems probable that the medicinal properties of oysters may depend upon these facts.

Copper and zinc are now known to be almost universally present in marine animals, even in situations where these metals cannot be detected in sea water.

There is no uniformity in the proportions of metals present in oysters.

Mercury, Barium and Lead have been tested for and found to be either definitely absent, or no evidence has been obtainable of their occurrence in analyses of oysters, soils, and tow-nettings, and are eliminated as causes of mortality. Aluminium is considered, and also not regarded as a likely cause of mortality.

Radio-active elements and antimony have not been tested for in oysters and soils, but no special reason has arisen to suspect these elements. Herdman and Boyce have shown that the blood-cells of the oyster contain much copper, but chemical analyses of blood-cells made at the Government Laboratory, and other facts indicate that most-if not all-of the metals in oysters are concentrated in the blood-cells.

An analysis of blood-cells taken from Mylor Bank oysters gave, in one million parts, approximately 5180 parts of copper, 8130 parts of zinc, 490 parts of tin and a trace of arsenic.

Other analyses show that the blood-cells contain far more metals than the oysters analysed as a whole, and particular oysters may contain a far greater proportion of metals than has been obtained from analyses of samples of soil taken at the same time as the oysters.

Oysters, therefore, accummulate metals from the surrounding medium, but also as is well known can clear themselves of metals to a great extent on being transplanted to a medium poor in metals. There is good reason to believe that this phenomenon is common to many Lamellibranchs. Thus it is clear that the blood-cells of the oyster-and other Lamellibranchs-are primarily concerned in the segregation and excretion of 
metals. It seems possible that metals are excreted by the blood-cells leaving the body of the oyster and carrying the metals with them.

\section{(5) Arsenic in Oysters and Solls.}

The absence of poisonous substances in solution in the sea water of the Thames Estuary led to a search for insoluble poisonous substances of which arsenic was one. Arsenic was found in oysters from the Thames Estuary in larger proportion than is allowed in food, both in sound oysters and supposed diseased oysters, but it was known that arsenic had been reported in American oysters (Wichmann) in small proportion, so that a more extensive examination of oysters, soils and other animals for arsenic was required to determine the relation of the presence of arsenic in oysters to the question of mortality.

The whole of the analyses for arsenic and other metals in oysters, soils, sea water and tow-nettings has been carried out by the staff of the Government Laboratory. Arsenic has now been found in sound and weak oysters from all localities where samples have been obtained for analysis Oysters have been been analysed whole, but the contents of the alimentary canal are smaller in amount on the average in the weaker oysters. The proportion of arsenic in weak oysters is, on the whole, greater-but not on the whole markedly greater-than in sound oysters, and varies from a trace - or none at all - in sound oysters to as much as five parts in a million of fresh oyster meat. In April, 1922, samples of sound and weak oysters taken at the same time from the oyster beds at Whitstable gave on analysis no arsenic in the sound oysters, but proportions of three and six parts in a million in the weak oysters; the whole of the analyses of oysters indicate a tendency to the accummulation of arsenic in the weaker oysters. The amount of arsenic found in sound oysters from the Mylor Bank beds - where arsenic occurs in the soil in great abundance, as has been shown by analyses - has been found to vary from nothing to as much as five parts in a million. The absence of arsenic in some of the oysters from these beds and the almost constant presence of arsenic in oysters from the Thames Estuary rendered it necessary to treat the problem carefully.

No pre-war analyses for arsenic of oysters, soils, sea water or townettings from the Thames Estuary are known, or believed, to have been made.

The amount of arsenic present in soils on the oyster beds and main channels in the Thames Estuary, in the sea water, and in tow-nettings of particles floating near the bottom has been determined and found to vary from twelve to sixty eight parts in a million of dried soil from the Oaze Deep (after removing the coarser particles), and smaller proportions from the oyster beds themselves, and from tow-nettings of floating particles. 
The amounts found are considered large and suspicious, and cannot yet be satisfactorily accounted for; it would appear that innocuous or on the other hand, dangerous commercial effluents or unknown dumpings containing arsenic may be the source.

It is possible, therefore, that the arsenic found in the Thames Estuary is in a different - and may possibly have occurred originally in a dangerous state - from that in the locality of Mylor Bank. No proof of any recent loss of arsenic in significant amount in the Thames Estuary has been obtained, but if it can be shown that arsenic in a dangerous state of combination has passed into the waters of the Thames Estuary prior to the summer of 1920, it will be necessary to carry out fresh investigations regarding arsenic and to review the whole of the data obtained in that light.

The blood-cells of oysters from Mylor Bank gave only a trace of arsenic on analysis, and the hearts of fifty weak oysters from Whitstable only two parts of arsenic in a milliom. The gut contents of oysters and bloodcells of weak oysters from the Thames area have not been analysed separately.

Arsenic and other metals have been estimated in silts from various localities: the proportion of arsenic found in the dried silt in parts per million at Mylor Bank was 835 to 1600 , at St. Just Pool, 100 to 225 , at Plymouth, in a few fathoms north of Drake's Island, 14 to 27, Helford River, 13, Blackwater River, 3 to 22 , near mouth of Colne River, 5 to 17 , off Whitstabel, 2 to 22.

Other animals than oysters have been analysed for arsenic; Pecten varius from Mylor Bank were found to contain 2.5 parts of arsenic per million, whilst similar specimens from St. Just Pool, taken on the same day, contained no arsenic; the sponge, Ficulina ficus, G.W. Docks, Plymouth, contained five parts per million, and Hymeniacidon sanguineum from the same locality contained three parts of arsenic per million on the wet weight. Similar amounts were found in the latter sponge from Falmouth.

Arsenic in sea water from the Blackwater River was found in the proportion of about three parts per hundred million, and a similar proportion in sea water from the Ham Grounds off Whitstable, and 2.5 parts per hundred million in water from the mouth of the English Channel.

Arsenic was found in tow-nettings consisting of floating particles and small living organisms, in proportions varying from a trace to thirty one parts per million (air-dried) in the Thames Estuary and a trace to seventeen parts per million (air-dried) in the Newton River, Isle of Wight. Further analyses of collections of the minute organisms alone are required to evaluate the results of analyses of tow-nettings containing both organisms and floating particles. Arsenic in traces, that is, of the order of 
one part in ten million has been found in the carapace of the crayfish, and smaller amounts still in the carapace of prawns and shrimps, (Gautier and Clausmann). The total evidence, however, indicates that the arsenic found in tow-nettings is present mainly in particles, and not in combination with organic substances derived from living organisms. The analyses of tow-nettings, therefore, show how the oysters in the Thames Estuary are obtaining their arsenic.

Iron pyrites from the Thames Estuary has been found to contain only traces of arsenic, namely, 0.01 per cent. and no arsenic was found in flints. Thus it would appear that local minerals will not account for the arsenic in the Thames Estuary, and, indeed, the accumulation found in the Oaze Deep suggests a recent source, not entirely accounted for by the apparently small amount of arsenic contained in thirty tons of arsenic refuse, dumped, however, in September, 1920.

Sound oysters yielding the maximum amount of arsenic found, namely, five parts of arsenic in one million parts of oyster meat contain about three and a half times more arsenic than is allowed in food (1/100 grain in a lb.). It would, however, be necessary to eat more than two dozen of such oysters to take the minimum daily dose given in the British Pharmacopœia. It has been pointed out by the Government Chemist that it would be necessary to consume 57 (fifty-seven) dozen oysters such as were present on the oyster-beds in August, 1921, (i.e., containing an average of 3.6 parts of arsenic per million and of an average weight of 8 grams) to take such a daily dose of arsenic as is allowed by the German Pharmacopœia.

As no pre-war analyses of English oysters (O. edulis) for arsenic are known, there is no evidence that these oysters did not contain similar amounts of arsenic then as now, and there is reason to believe that all oysters at some time may contain arsenic, and that in that case their edibility may be no different, or little different now, from formerly(Vide analyses of Lachryan oysters). There is no doubt that sound oysters have remained edible - as regards arsenic content or otherwise-during the course of these investigations. It is recommended, however, that periodical analyses of oysters should be made by the Government Chemist until the amount of arsenic in oysters is satisfactorily accounted for.

Oysters can be kept in sea water in bell-jars containing white arsenic for many months without harm; such oysters have been found by analysis to contain as much as twenty one parts of arsenic as $\mathrm{As}_{4} \mathrm{O}_{6}$ in 2 million, Under these conditions oysters apparently easily absorb and easily lose the absorbed arsenic. Oysters in arsenicated sea water give off continuously for months an arsenicated gas resembling - and probably identical with-arsine; thus the living oysters react in some way at present unknown with arsenic. The amounts of arsenicated gas produced 
daily are minute, but recognisable easily by the strong characteristic odour. The experiment with controls is easily performed. The possibility of using oysters as a test for arsenic, as $\mathrm{As}_{2} \mathrm{O}_{3}$, is suggested.

The mode of absorption and retention of arsenic in oysters is not known, and there are indications that arsenic is held differently in oysters from copper and zinc.

The amount of arsenic in oysters, it is pointed out, is relatively very small compared with that of copper which can be held with impunity, reaching a ratio as high as 1 to 660 for the maximum amount of arsenic and 1 to 1300 for about the average amount.

Instances are given of substances accumulated in abundance in animals from sea water containing only traces of those substances. Arsenic as well as copper, zinc, barium and iron, has been shown to be present in sea water in traces

An arsenicated paint which was just losing its toxicity to Obelia sp., probably 0 . geniculata, after three and a half years immersion in the sea was found to contain 0.4 per cent. of arsenic as $\mathrm{As}_{4} \mathrm{O}_{6}$.

Thus until more information is available as to the condition now, and formerly, of the arsenic found in the Thames Estuary, and of the reactions of oysters to arsenic compounds, it is not possible to connect the occurrence of arsenic in oysters with an unusual mortality of oysters, and it may well be that all oysters may at some time contain arsenic in approximately the amounts here recorded.

\section{(6) Sodium Picrate.}

Experiments carried out with picric acid on oysters-and unpublished experiments carried out by Allen and Lebour with sodium picrate for the Ministry of Agriculture and Fisheries-show that these substances are only slightly toxic in sea water, and that toxic solutions would give a distinctive colour to the water. The dumpings of this material are considered, and the conclusion arrived at that sodium picrate can be eliminated as a likely cause of death of oysters in 1920 .

\section{B. ISLE OF WIGHT AND SWANSEA AREAS.}

The mortality among oysters in the Isle of Wight area differs from all others in being reported in the winter of 1920-21, but as the mortality was reported to have ceased in January, 1921, a large portion of the mortality may have occurred undetected in the summer of 1920 . No cause of the mortality was detected in the investigations carried out, but information regarding dangerous cargoes of munitions lost in the vicinity during the war renders further enquiries necessary to estimate the possible 
effect of the lost munitions on oysters. The information mentioned was received only recently, and too late for the writer to prosecute further enquiries.

It is noteworthy that some oysters from the Isle of Wight area contained relatively large amounts of arsenic, although copper and zinc were absent.

Little information was obtained from Swansea, other than the reports of unusual mortality of oysters, but indications were obtained from inspections of the beds that other animals on the oyster beds and in the vicinity had been healthy in the preceding summer. The mortality appeared to have ceased after the receipt of the reports and no cause of the reported mortality has been found.

\section{Experiments on Oysters.}

It is known that oysters may acquire a weakness which may not be shown until after the lapse of a considerable period, and that the summer time is a critical one for all oysters. In experiments on oysters it is essential to bear these facts in mind. Moreover, oysters will vary in condition at the same time of the year in different localities, so that locality, actual date of transport, and conditions of transport, as well as the time of the year transported, and the length of time oysters have been relaid, whether on the beds or in tanks, have all to be taken into consideration in beginning an experiment. To complete observations on oysters which have been experimented upon, it is advisable to record the conditions of oysters over a considerable period - in months - after the conclusion of the experimental conditions. As oysters will usually live in tanks during the winter with a low mortality rate, even when not in very good condition, the winter period is a very good one for differentiating mortality due to experimental conditions. The complex conditions of oysters render it advisable always to carry out exact control experiments even if the tank space available be small, and the number of experiments to be carried out simultaneously be thereby reduced.

The ideal experiment on oysters is carried out in the sea ; the nearest approach to this condition is to subject oysters to experimental conditions in the laboratory and afterwards transplant the oysters in isolation in the sea.

\section{CONCLUSION.}

The lack of reliable information regarding normal mortality in native and relaid oysters has needed to be borne in mind during the whole course of the investigations, and it is regarded as probable that the normal mortality may be much higher than is realised or acknowledged by oyster- 
eultivators. It may be said that the oyster is a domesticated animal, and as such may be subjected to treatment resulting at times in grave constitutional disorders, and consequently in a high rate of mortality. It is the residual mortality derived from deducting the normal from the total of the unusual that has to be accounted for. It is considered possible that a fraction of this residual mortality may be accounted for by abnormal weather in shallow water and river beds, and by pests on the beds off Whitstable, but it is further considered unlikely that these increments would account for the whole residual mortality estimated by the oyster planters, who are the only bodies in a position to make approximately reliable estimates.

It seems possible that whatever is causing the inflammatory conditions observed in oysters, may account for a further fraction of the residual mortality, but, on the other hand, these inflammatory appearances may be of normal occurrence and may need to be included in the normal causes which lead to death.

It has been shown that T.N.T. could not have been the cause of unusual mortality, and that it is highly probable that arsenic is not a cause of unusual mortality, and that no evidence nor knowledge of the presence in oysters or sea water of any other poisonous substance which is a probable cause of abnormal mortality has been obtained. It is shown, however, that a knowledge of the materials which may have passed into the Thames Estuary is incomplete.

Thus no poison has been found to explain an unusual mortality. At the same time no parasite has been found to explain unusual mortality, and although it is impossible to say that oysters have not been dying owing to parasitic attacks, it is considered extremely unlikely that any dangerous parasite of an infectious nature was present in oysters after November, 1920.

Of the oysters dying from no apparent cause it has been shown that a good proportion contained abundance of myolytic spindles in their tissues. Myolysis has not previously been described in oysters, and although the phenomenon is regarded as probably normal, yet it is considered that the condition of excessive myolysis is pathological.

The failure to find a satisfactory cause of the unusual mortality in either weather effects, poisons, parasites, or pests may be due to absence of information or failure to recognise some feature or fact under either of these branches of the work, or, on the other hand, may be due to (1) the possibility that the cause of the unusual mortality in 1920 disappeared by the time the investigations were undertaken - when the mortality was said to be over-or (2) that oyster planters may in good faith have overestimated the mortality in 1920-although this seems improbable in many cases - and that the mortality in 1921 was what might be expected. 
It is shown however, that no single cause or group of causes has been found singly or collectively to account for a heavy and unusual mortality of oysters in the Thames Estuary in the summer of 1920, but it would appear that the discovery of the cause of excessive myolysis - a condition heretofore undescribed in oysters-observed in hockley oysters in good condition, might lead to a satisfactory cxplanation of that portion of the mortality which cannot be included in the normal. 